\title{
Migration and differentiation of gonadal germ cells under cross-sex germline chimeras condition in domestic chickens
}

\author{
Yuki NAKAJIMA ${ }^{1,2)}$, Tetsuya HATTORI ${ }^{3)}$, Atsushi ASANO ${ }^{1)}$, Naoto ISHIKAWA ${ }^{1)}$ and \\ Atsushi TAJIMA ${ }^{1)}$ \\ 1) Faculty of Life and Environmental Sciences, University of Tsukuba, Ibaraki 305-8572, Japan \\ 2) Fellow of the Japanese Society for the Promotion of Science \\ ${ }^{3)}$ Graduate School of Life and Environmental Sciences, University of Tsukuba, Ibaraki 305-8572, Japan
}

\begin{abstract}
A series of experiments was conducted to investigate migration, proliferation and differentiation of gonadal germ cells (GGCs) collected from the gonads of 7-day-old chick embryos under cross-sex germline chimera conditions. The migratory and proliferative abilities of exogenous GGCs were examined by transferring 50 fluorescently labeled GGCs collected from White Leghorn (WL) embryos into the blood of 2-day-old Rhode Island Red (RIR) embryos. No significant difference was observed in the number of fluorescently labeled GGCs in the gonads of recipient embryos among any of the four possible donor and recipient sex combinations. Cross-sex germline chimeras were produced to examine the differentiation of GGCs by transferring 100 GGCs from WL embryos into 2-day-old RIR embryos. Exogenous-GGC-derived progeny were obtained from both male and female recipients, except when female GGCs were transferred into male recipients. The migratory ability of GGCs recovered from the 7-day-old embryonic gonad was not influenced by cross-sex germ cell transfer conditions, whereas the differentiation of the GGCs was affected by the sex combinations of GGCs donors and recipients.
\end{abstract}

Key words: Avian, Cross-sex germline chimera, Gonadal germ cells, 7-Day-old embryo

(J. Reprod. Dev. 60: 406-410, 2014)

G ermline development is one of the most fundamental topics in reproductive biology. In avian species, germline development can be experimentally manipulated through the cross-sex germline chimera produced by the transfer of progenitor cells of gametes, known as primordial germ cells (PGCs). Avian PGCs are reported to originate from the central zone of the area pellucida [1, 2]. At the primitive streak stage, PGCs are located in an extraembryonic region called the germinal crescent [3]. The PGCs circulate temporarily through the bloodstream, followed by migration to the gonadal ridge $[4,5]$, after which they are called gonadal germ cells (GGCs). GGCs ultimately differentiate into oogonia in the female embryo and spermatogonia in the male embryo [5].

Germline chimeras can be produced by transferring PGCs collected from circulating blood of early developing 2-day-old embryos into recipient embryos [6]. More recently, germline chimeras were successfully produced by transferring GGCs collected from 5-, 7- and 9-day-old embryonic gonads $[7,8]$.

Production of cross-sex germline chimeras has been reported by transferring blastodermal cells or PGCs into recipient embryos of the opposite sex [2,9]. It was shown that the blastodermal cells have the ability to differentiate into both sperm and ova, regardless of their

Received: October 16, 2013

Accepted: July 13, 2014

Published online in J-STAGE: August 16, 2014

(C2014 by the Society for Reproduction and Development

Correspondence: A Tajima (e-mail: tajima.atsushi.gb@u.tsukuba.ac.jp)

This is an open-access article distributed under the terms of the Creative Commons Attribution Non-Commercial No Derivatives (by-nc-nd) License $<\mathrm{http}: / /$ creativecommons.org/licenses/by-nc-nd/3.0/>. genetic sex [2]. In contrast, progeny derived from exogenous PGCs was rarely produced under cross-sex germ cell transfer conditions [9]. Particularly, W chromosome-bearing female PGCs hardly ever complete subsequent spermatogenesis in the recipient's testis [10]. Thus, the efficiency of PGC differentiation into functional gametes under cross-sex transfer conditions may be limited compared with cross-sex blastodermal cell transfer. However, the fate of exogenous GGCs under cross-sex germ cell transfer conditions has not been examined.

Therefore, the present study was conducted to investigate the fate of exogenous GGCs, recovered from gonads of 7-day-old chick embryos, under cross-sex germ cell transfer conditions.

\section{Materials and Methods}

\section{Recovery of GGCs}

Fertilized White Leghorn (WL) and Rhode Island Red (RIR) eggs produced at the Agriculture and Forestry Research Center, University of Tsukuba, Japan, were used in the experiments. Fertilized WL eggs were incubated for 7 days in an air-forced incubator (P-008; Showa Furanki Laboratory, Saitama, Japan) maintained at 37.8 C. After incubation, GGCs were isolated from embryonic gonad by the using PBS[-] method according to the method reported by Nakajima et al. [11]. Briefly, both the right and left gonads were isolated from 7-dayold embryos. Isolated gonads were placed in $1.5-\mathrm{ml}$ centrifuge tubes containing $100 \mu$ of Dulbecco's phosphate-buffered saline without $\mathrm{Ca}^{2+}$ and $\mathrm{Mg}^{2+}$ (PBS[-]; cat. no. 05913; Nissui, Tokyo, Japan). The centrifuge tubes were placed in an incubator maintained at $37.8 \mathrm{C}$ for approximately $1 \mathrm{~h}$. The morphological characteristics of the isolated 
GGCs were identical to those of PGCs, i.e., large granulated round cells with large nuclei [12] under an inverted microscope (IMT-2; Olympus, Tokyo Japan). Polymerase chain reaction (PCR) was performed to determine the sex of the germ cell donors.

\section{Migratory ability of the GGCs}

After recovery, the GGCs were labeled with PKH26 fluorescent dye (cat. no. Z-PKH26-GL; Zynaxis, Malvern, PA, USA), and 50 GGCs were injected into the dorsal aorta of RIR embryos at stages 13-16 of development [13] for all four possible sex combinations. Throughout the present study, GGC transfer was carried out using a fine glass pipette under a dissection microscope. Recipient eggs were prepared $1 \mathrm{~h}$ before injection to remove approximately $3 \mu \mathrm{lof}$ blood through a small window (approximately $1 \mathrm{~cm}$ in diameter) in the eggshell. After injection, the window was sealed with plastic tape, and the egg was incubated at $37.8 \mathrm{C}$ for 5 days. The right and left gonads were collected from recipient embryos and placed in $1.5-\mathrm{ml}$ centrifuge tubes containing $50 \mu \mathrm{l}$ of $0.05 \%$ trypsin in PBS[-] and incubated at $37.8 \mathrm{C}$ for $20 \mathrm{~min}$. After incubation, the cells were placed on a 2-well Hard Teflon-Coated Slide (HTCS, cat. no. 10-226-CC; Erie Scientific, Portsmouth, NH, USA), and the total number of fluorescently labeled cells recovered from each gonad was counted under a fluorescence microscope (IMT-2; Olympus, Tokyo Japan) using a 546-nm excitation filter. PCR was performed to determinate the sex of the germ cell donors and recipients. A split-plot design was used to conduct the experiment, and the data were analyzed using the generalized linear model (GLM; SAS/STAT, SAS Institute, Cary, NC, USA) followed by Tukey's Honestly Significant Difference (HSD) test using SAS/STAT.

\section{Production of germline chimeras}

Aliquots of $100 \mu \mathrm{l}$ of GGC suspension were placed on 2-well HTCSs. Then, 100 GGCs were injected into the dorsal aorta of RIR embryos at stages 13-16 of development for all four possible sex combinations. Recipient eggs were prepared $1 \mathrm{~h}$ before injection to remove approximately $3 \mu \mathrm{l}$ of blood through a small window in the eggshell. PCR was performed to determinate the sex of the germ cell donors. After injection, the window was sealed with plastic tape, and the embryo was allowed to develop until hatching. Hatched chicks were raised beyond sexual maturity so that progeny testing could be performed by mating GGC recipients with RIR chickens of the opposite sex. WL chickens carry the homozygous dominant pigment inhibitor gene $(I / I)$, whereas RIR chickens carry the homozygous recessive pigment inhibitor gene $(i / i)$. Therefore, the identity of the spermatozoa or ova produced from germline chimeras could be ascertained by observing the feather color of the newly hatched chicks.

All animal care and handling procedures were performed in accordance with the standards of the University of Tsukuba.

\section{PCR for sexing}

Embryonic skin tissue was collected from the leg of each embryo. The samples were placed in DNA extraction buffer [14], proteinase $\mathrm{K}$ was added to a final concentration of $200 \mu \mathrm{g} / \mathrm{ml}$, and incubation was performed for $24 \mathrm{~h}$ at $37.8 \mathrm{C}$. After centrifugation $(10,000 \times \mathrm{g}$, 5 min, 4 C), PCR was performed. A 276-bp fragment of the 717-bp $\mathrm{W}$ chromosome-specific XhoI repetitive sequence was amplified according to the methods of Petitte and Kegelmeyer [15] using the following primers: 5'-CGTGAGAAAAGTGGTAGTT-3' and 3'-CTCTGTCCACCATAAAAACC-5'.

PCR was conducted in a PCR Thermal Cycler SP (TP-400; Takara Shuzo, Kyoto, Japan) with an initial denaturation step at $96 \mathrm{C}$ for 2 min followed by 25 cycles at $94 \mathrm{C}$ for $30 \mathrm{sec}, 52 \mathrm{C}$ for $30 \mathrm{sec}$, and $72 \mathrm{C}$ for $30 \mathrm{sec}$, with a final extension step at $72 \mathrm{C}$ for $5 \mathrm{~min}$. The PCR products were separated by electrophoresis on a $1.5 \%$ agarose gel and visualized under ultraviolet (UV) light after staining with ethidium bromide. Only samples that were obtained from females were expected to express the 276-bp PCR product.

\section{Analysis of semen from germline chimeras by PCR using breed-specific markers}

Semen was collected from each male germline chimera. DNA was extracted by a previously described method and purified using the standard method of phenol/chloroform extraction and precipitation with ethanol as described by Sambrook et al. [16]. A PCR analysis was performed after dissolving DNA in Tris-EDTA at a concentration of $100 \mathrm{ng} / \mu \mathrm{l}$. The sequences of the primers for detecting the dominant white-specific (I) AS3554-I9 repetitive sequence [17] were 5'-AGCAGCGGCGATGAGCGGTG-3' and 3'-CTGCCTCAACGTCTCGTTGGC-5', and those for the recessive allele-specific $(i)$ AS3554-WT repetitive sequence [17] were 5'-AGCAGCGGCGATGAGCAGCA-3' and 3'-CTGCCTCAACGTCTCGTTGGC-5'. These sequences were amplified according to the method described by Naito et al. [18], with a slight modification. The primers used in the present study for identifying RIR and WL chickens were validated in a preliminary experiment (data not shown). PCR was conducted in a Takara PCR Thermal Cycler SP with an initial denaturation step at $94 \mathrm{C}$ for 5 min, followed by 35 cycles at $94 \mathrm{C}$ for $30 \mathrm{sec}$ and $72 \mathrm{C}$ for $30 \mathrm{sec}$, with a final extension step at $72 \mathrm{C}$ for $5 \mathrm{~min}$. The PCR products were separated by electrophoresis on a $1 \%$ agarose gel and visualized under UV light after staining with ethidium bromide. Samples that were obtained from WL and RIR chickens were expected to express the 222-bp and 213-bp PCR products, respectively.

\section{Results}

\section{Migratory ability of the GGCs}

Table 1 shows the migratory ability of 7-day-old GGCs in recipient embryonic gonads. When fluorescently labeled GGCs were transferred into recipient embryos, fluorescence-positive GGCs, as identified by their morphology, were detected from the right and left gonads of recipient embryos. The number of fluorescence-positive GGCs was higher in the left gonad compared with the right gonad in all four sex combinations $(\mathrm{P}<0.05)$. However, the number of fluorescence-positive GGCs observed in recipient embryos was not significantly different among the four possible sex combinations between exogenous GGCs and recipient embryos $(\mathrm{P}>0.05)$.

\section{Analysis of semen from germline chimeras by PCR using breed-specific markers}

The results of PCR analysis of semen collected from putative male germline chimeras using breed-specific markers are shown in Fig. 1. 
Table 1. Number of PKH26-positive gonadal germ cells recovered from 7-day-old chick embryonic gonads observed in the gonads of recipient embryos $(n=40$, means $\pm S E)$

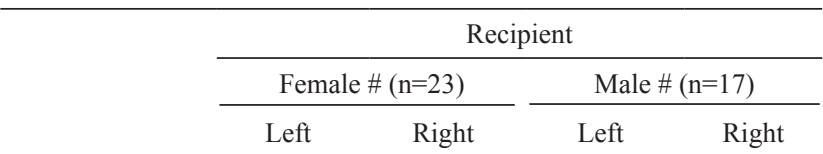

\section{Donor}

Female \# (n=26) $43.8 \pm 9.4^{\mathrm{a}} \quad 32.5 \pm 13.8^{\mathrm{b}} \quad 45.9 \pm 10.6^{\mathrm{a}} \quad 28.3 \pm 4.0^{\mathrm{b}}$ Male \# $(\mathrm{n}=14) \quad 48.9 \pm 10.8^{\mathrm{a}} \quad 39.0 \pm 16.8^{\mathrm{b}} \quad 51.2 \pm 8.2^{\mathrm{a}} \quad 34.8 \pm 6.7^{\mathrm{b}}$

The number of fluorescence-positive GGCs observed in recipient embryos was not significantly different among the four possible sex combinations of exogenous GGCs and recipient embryos (P > 0.05). $\mathrm{a}, \mathrm{b}$ The numbers of fluorescence-positive GGCs with different letters are significantly different between the left and right gonads of the recipient embryos at $\mathrm{P}<0.05$.
The semen collected from three male recipients by resulting from transfer of male GGCs $(\mathrm{M} \rightarrow \mathrm{M}$ chimeras, No. 3, 7 and 8) and two male recipients by resulting from transfer of female GGCs $(\mathrm{F} \rightarrow \mathrm{M}$ chimeras, No. 2 and 6) was used for analysis. The concentration of spermatozoa in semen ranged from $1.6 \times 10^{9}$ to $3.5 \times 10^{9} / \mathrm{ml}$. A clear DNA band derived from exogenous GGCs was observed in 2 out of $3 \mathrm{M} \rightarrow \mathrm{M}$ chimeras (No. 3 and 7) (Fig. 1A). A recipient-derived DNA band was detected in all putative germline chimeras (Fig. 1B).

\section{Progeny testing of putative germline chimeras}

The results of progeny testing are shown in Table 2. GGCs were transferred into 56 recipient embryos, and 27 chicks hatched. Of these, 16 chickens matured and were test mated. The numbers of individuals grown to sexual maturity were one female recipient by resulting from transfer of female GGCs $(\mathrm{F} \rightarrow \mathrm{F}$ chimera), seven
A.

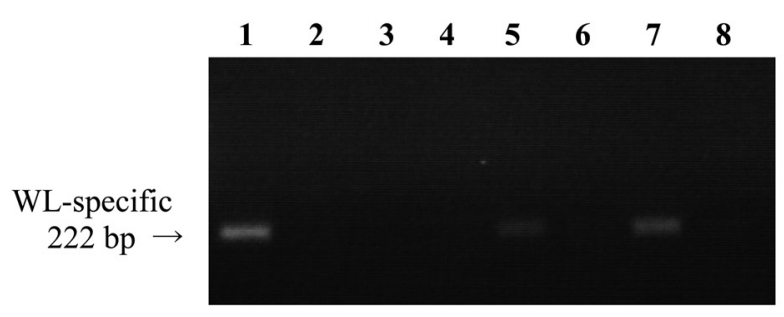

B.

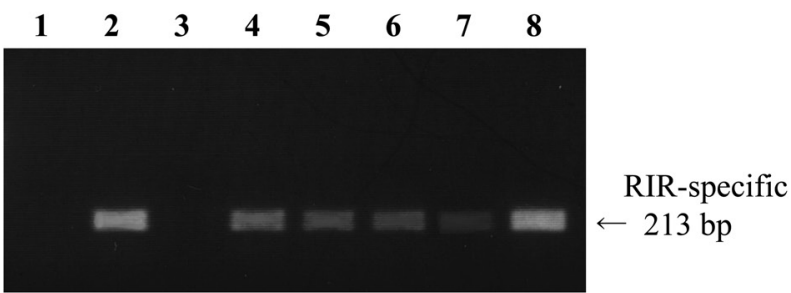

Fig. 1. Analysis of semen samples of male germline chimeras produced by transfer of female and male gonadal germ cells collected from 7-day-old embryonic gonads. DNA was extracted from the sperm samples and analyzed for the presence of (A) dominant white-specific repeat sequences by PCR with dominant white-specific primers and (B) recessive allele-specific repeat sequences by PCR with recessive allele-specific primers. Lane 1, control (White Leghorn sperm DNA); lane 2, control (Rhode Island Red sperm DNA); lane 3, negative control (water); lane 4, ID no. $\mathrm{F} \rightarrow \mathrm{M} 2$ (male germline chimera produced by transfer of female gonadal germ cells); lane 5, ID no. M $\rightarrow \mathrm{M} 3$; lane 6, ID no. F $\rightarrow \mathrm{M} 6$; lane 7, ID no. $\mathrm{M} \rightarrow \mathrm{M} 7$; lane 8 , ID no. $\mathrm{M} \rightarrow \mathrm{M} 8$.

Table 2. Progeny test of Rhode Island Red chickens receiving 100 gonadal germ cells collected from 7-day-old White Leghorn embryos

\begin{tabular}{|c|c|c|c|c|c|c|c|}
\hline ID & Donor & Recipient & $\begin{array}{l}\text { Experimental period } \\
\text { (week) }\end{array}$ & $\begin{array}{c}\text { No. of eggs } \\
\quad \text { laid }\end{array}$ & $\begin{array}{c}\text { No. of fertilized } \\
\text { eggs }\end{array}$ & $\begin{array}{l}\text { No. of hatched } \\
\text { chicks }\end{array}$ & $\begin{array}{l}\text { No. of white feather } \\
\text { chicks }(\%)\end{array}$ \\
\hline $\mathrm{F} \rightarrow \mathrm{F} 14$ & Female & Female & 33 & 216 & 195 & 138 & $3(2.2 \%)$ \\
\hline $\mathrm{M} \rightarrow \mathrm{M} 3$ & Male & Male & 14 & 356 & 315 & 245 & $0(0 \%)$ \\
\hline $\mathrm{M} \rightarrow \mathrm{M} 7$ & Male & Male & 5 & 132 & 120 & 99 & $27(27.3 \%)$ \\
\hline $\mathrm{M} \rightarrow \mathrm{M} 8$ & Male & Male & 10 & 220 & 152 & 92 & $0(0 \%)$ \\
\hline $\mathrm{F} \rightarrow \mathrm{M} 1$ & Female & Male & 12 & 316 & 298 & 258 & $0(0 \%)$ \\
\hline $\mathrm{F} \rightarrow \mathrm{M} 2$ & Female & Male & 12 & 318 & 288 & 232 & $0(0 \%)$ \\
\hline $\mathrm{F} \rightarrow \mathrm{M} 4$ & Female & Male & 4 & 70 & 59 & 33 & $0(0 \%)$ \\
\hline $\mathrm{F} \rightarrow \mathrm{M} 6$ & Female & Male & 14 & 345 & 313 & 224 & $0(0 \%)$ \\
\hline $\mathrm{F} \rightarrow \mathrm{M} 9$ & Female & Male & 4 & 61 & 45 & 25 & $0(0 \%)$ \\
\hline $\mathrm{M} \rightarrow \mathrm{F} 11$ & Male & Female & 41 & 278 & 267 & 216 & $0(0 \%)$ \\
\hline $\mathrm{M} \rightarrow \mathrm{F} 12$ & Male & Female & 36 & 225 & 202 & 163 & $0(0 \%)$ \\
\hline $\mathrm{M} \rightarrow \mathrm{F} 13$ & Male & Female & 36 & 232 & 222 & 191 & $1(0.5 \%)$ \\
\hline $\mathrm{M} \rightarrow \mathrm{F} 15$ & Male & Female & 34 & 230 & 214 & 191 & $0(0 \%)$ \\
\hline $\mathrm{M} \rightarrow \mathrm{F} 16$ & Male & Female & 34 & 204 & 180 & 143 & $1(0.7 \%)$ \\
\hline
\end{tabular}


$\mathrm{F} \rightarrow \mathrm{M}$ chimeras, three $\mathrm{M} \rightarrow \mathrm{M}$ chimeras, and five female recipients by resulting from transfer of male GGCs ( $\rightarrow$ F chimeras). White feathered progenies were obtained from one male and three female GGC recipients, whereas donor-derived progeny were obtained only when female GGCs were transferred into female embryos. Donorderived progeny were obtained when male GGCs were transferred into both female and male embryos. The ratios of chimeric chickens that produced donor-derived offspring were higher in $\mathrm{M} \rightarrow \mathrm{M}$ chimeras $(0-27.3 \%)$ and $\mathrm{F} \rightarrow \mathrm{F}$ chimera $(2.2 \%)$, whereas the percentages of germline chimeric chickens was lower in $\mathrm{F} \rightarrow \mathrm{M}$ chimeras $(0 \%)$ and $\mathrm{M} \rightarrow \mathrm{F}$ chimeras $(0-0.7 \%)$.

\section{Discussion}

The present study was performed to elucidate migration, proliferation and subsequent differentiation of GGCs recovered from gonads of 7-day-old chick embryos into functional gametes under cross-sex germ cell transfer conditions.

It was shown that the number of fluorescently labeled exogenous GGCs in the recipient's left gonad was significantly higher compared with that in the right gonad $(\mathrm{P}<0.05)$. This result is consistent with the previous studies, which showed that the circulating PGCs and GGCs migrate in favor of the left gonad after transfer into recipient embryos $[11,19]$. It is widely known that the right gonad starts to regress in the early stage of embryonic development in female and that only the left gonad develops into a functional ovary [20]. The higher number of GGCs found in the left ovary is presumably related to the regression of the right ovary during embryogenesis. In males, on the other hand, both the right and left gonads develop into functional testes. However, it has been reported that testicular development is also asymmetrical, with the left testis being larger in many avian species [21]. The higher number of GGCs found in the left testis could be related to asymmetrical development of the testis. However, the underlying mechanism of the left-gonad-biased germ cell distribution of GGCs in males is likely to be different from that in females, since the differences in the size of the right and left testes are minute compared with the ovary.

Despite the significant differences observed in the progeny testing, the migratory and proliferative abilities of GGCs were not significantly different among any of the four possible donor and recipient sex combinations in the present study $(\mathrm{P}>0.05)$. It has been reported that the ability to migrate into the gonads of recipient embryos persisted in chick GGCs recovered from 6.5- to 20.5-day-old embryos [22]. These results indicate that germ cells pertain the migratory ability for an extended period of time during embryonic development. Furthermore, chick PGCs was reported to migrate into the germinal ridge of quail embryos $[12,23]$. Therefore, the mechanism of germ cell migration seems to be shared between avian species. It has been reported that a peptide chemokine, namely, stromal cell-derived factor 1 (SDF-1), secreted from the embryonic gonad, which induces PGCs to migrate toward the embryonic gonad, and expression of the receptor for SDF-1, C-X-C chemokine receptor-4 (CXCR4), were observed in Zebrafish [24, 25] and mice [26, 27]. Chicken SDF-1 has been also indicated to induce the migration of PGCs into the intermediate mesoderm, planned the gonadal region [28]. However, the effects of these molecules on PGC migration into the gonad has not been directly reported. Therefore, studies to unveil the underlying mechanism of germ cell migration, one of the fundamental questions concerning germline development, need to be carried out in the future.

Fifty GGCs transferred into recipient embryos increased significantly to $80.5 \pm 11.0$ on average at 5 days post transfer $(\mathrm{P}<0.05)$. A WL-specific DNA band was detected by PCR in semen collected from $\mathrm{M} \rightarrow \mathrm{M}$ chimeras, whereas no WL-specific DNA band was observed from $\mathrm{F} \rightarrow \mathrm{M}$ chimeras (Fig. 1). These results indicate that donor GGCs proliferated after migrating into the male recipient embryonic gonads in $\mathrm{M} \rightarrow \mathrm{M}$ chimeras, whereas differentiation into spermatozoa was limited in $\mathrm{F} \rightarrow \mathrm{M}$ chimeras. To confirm the differentiating ability of GGCs collected by the PBS[-] method [11], germline chimeras were produced under identical-sex combinations. The percentages of donor-derived offspring in $\mathrm{F} \rightarrow \mathrm{F}$ and $\mathrm{M} \rightarrow \mathrm{M}$ germline chimeras were $2.2 \%(3 / 138)$ and $27.3 \%(27 / 99)$, respectively (Table 2). On the other hand, the percentages of donor-derived offspring in $\mathrm{M} \rightarrow \mathrm{F}$ and $\mathrm{F} \rightarrow \mathrm{M}$ germline chimeras were $0.5-0.7 \%$ and $0 \%$, respectively (Table 2 ). Therefore, it is speculated that the probability of producing progeny from germline chimeras was lower under the cross-sex germ cells transfer conditions compared with the identical-sex germ cell transfer conditions. Donor-derived offspring have been retrieved from blastodermal chimeras produced by removing and transferring stage $\mathrm{X}$ blastodermal cells, regardless of their genetic sex [2]. On the other hand, Naito et al. [9] reported that the efficiency of producing germline chimeras was significantly lower when the chromosomal sex was different between the donor PGCs and recipient embryos. Moreover, PGCs differentiate into complete sperm, but at an extremely low rate when female PGCs are transferred into male recipients [10]. These results indicate that the sexual differentiation of PGCs further progresses after migration into the developing gonads. From the practical point of view, it is highly inefficient to produce germline chimeras when female PGCs or GGCs are transferred into male recipients.

Aromatase, a key enzyme in the conversion of testosterone to $17 \beta$-estradiol, is known to play a pivotal role in female sexual differentiation [29]. The aromatase gene was initially expressed in the gonads of female chick embryos on day 6.5 of incubation [30]. Therefore, the female 7-day-old GGCs used in the present study may have been influenced by gonadal feminization.

It was shown that 7-day-old GGCs could be used to produce male and female germline chimeric chickens in the present study. As far as the authors are aware, this is the first study on successful production of female germline chimeras after transfer of 7-day-old GGCs. Our results provide new possibilities for conserving avian genetic resources using GGCs from 7-day-old chick embryos.

The migratory ability of germ cells into the gonad and subsequent differentiation into gametes has been reported [7, 8, 10, 22, 31]. However, the quantitative relationship between migratory ability and germ cell differentiation has not been critically evaluated. Our results indicate that the migratory ability of germ cells into the gonad and subsequent differentiation into gametes are independent. It can be summarized that the migratory ability of GGCs is a necessary but not sufficient condition to produce germline chimeras.

In conclusion, the migratory ability of GGCs was not affected by cross-sex combination germ cell transfer, whereas the differentiation 
of GGCs was influenced by the sex combinations of germ cell donors and recipients.

\section{Acknowledgments}

The authors thank the staff of the Animal Science Division of the Agricultural and Forestry Research Center, University of Tsukuba, for their technical support. This study was funded by a Research Fellowship for Young Scientists from the Japan Society for the Promotion of Science to YN.

\section{References}

1. Ginsburg M, Eyal-Giladi H. Primordial germ cells of the young chick blastoderm originate from the central zone of the area pellucida irrespective of the embryo-forming process. Development 1987; 101: 209-219. [Medline]

2. Kagami H, Tagami T, Matsubara Y, Harumi T, Hanada H, Maruyama K, Sakurai M, Kuwana T, Naito M. The developmental origin of primordial germ cells and the transmission of the donor-derived gametes in mixed-sex germline chimeras to the offspring in the chicken. Mol Reprod Dev 1997; 48: 501-510. [Medline] [CrossRef]

3. England MA, Matsumura G. Primordial germ cells in the primitive streak stages chick embryo as studied by scanning electron microscopy. J Anat 1993; 183: 67-73. [Medline]

4. Fujimoto T, Ukeshima A, Kiyofuji R. The origin, migration and morphology of the primordial germ cells in the chick embryo. Anat Rec 1976; 185: 139-153. [Medline] [CrossRef]

5. Kuwana T. Migration of avian primordial germ cells toward the gonadal anlage. Dev Growth Differ 1993; 35: 237-243. [CrossRef]

6. Tajima A, Naito M, Yasuda Y, Kuwana T. Production of germ line chimera by transfer of primordial germ cells in the domestic chicken (Gallus domesticus). Theriogenology 1993; 40: 509-519. [Medline] [CrossRef]

7. Tajima A, Naito M, Yasuda Y, Kuwana T. Production of germ-line chimeras by transfer of cryopreserved gonadal primordial germ cells (gPGCs) in chicken. J Exp Zool 1998; 280: 265-267. [Medline] [CrossRef]

8. Tajima A, Minematsu T, Ohara M. Production of germ-line chimeras by the transfer of cryopreserved gonadal germ cells collected from 7- and 9-day-old chick embryos. Anim Sci J 2004; 75: 85-88. [CrossRef]

9. Naito M, Matsubara Y, Harumi T, Tagami T, Kagami H, Sakurai M, Kuwana T. Differentiation of donor primordial germ cells into functional gametes in the gonads of mixed-sex germline chimaeric chickens produced by transfer of primordial germ cells isolated from embryonic blood. J Reprod Fertil 1999; 117: 291-298. [Medline] [CrossRef]

10. Tagami T, Kagami H, Matsubara Y, Harumi T, Naito M, Takeda K, Hanada H, Nirasawa K. Differentiation of female primordial germ cells in the male testes of chicken (Gallus gallus domesticus). Mol Reprod Dev 2007; 74: 68-75. [Medline] [CrossRef]

11. Nakajima Y, Minematsu T, Naito M, Tajima A. A new method for isolating viable gonadal germ cells from 7-day-old chick embryos. J Poult Sci 2011; 48: 106-111. [CrossRef]

12. Yasuda Y, Tajima A, Fujimoto T, Kuwana T. A method to obtain avian germ-line chimaeras using isolated primordial germ cells. J Reprod Fertil 1992; 96: 521-528. [Medline] [CrossRef]

13. Hamburger V, Hamilton HL. A series of normal stages in the development of the chick embryo. J Morphol 1951; 88: 49-92. [Medline] [CrossRef]
14. Minematsu T, Sugiyama M, Tohma Y, Tajima A, Kanai Y. Simplified DNA extraction methods for sexing chick embryos. J Poult Sci 2004; 41: 147-154. [CrossRef]

15. Petitte JN, Kegelmeyer AE. Rapid sex determination of chick embryos using the polymerase chain reaction. Anim Biotechnol 1995; 6: 119-130. [CrossRef]

16. Sambrook J, Fritsch EF, Maniatis T. Molecular Cloning: A Laboratory Manual, 2nd eds. Cold Spring Harbor, NY: Cold Spring Harbor Laboratory Press; 1989.

17. Choi JW, Lee EY, Shin JH, Zheng Y, Cho BW, Kim JK, Kim H, Han JY. Identification of breed-specific DNA polymorphisms for a simple and unambiguous screening system in germline chimeric chickens. J Exp Zool A Ecol Genet Physiol 2007; 307: 241-248. [Medline] [CrossRef]

18. Naito M, Harumi T, Kuwana T. Expression of GFP gene in cultured PGCs isolated from embryonic blood and incorporation into gonads of recipient embryos. J Poult Sci 2012; 49 : 116-123. [CrossRef]

19. Naito M, Minematsu T, Harumi T, Kuwana T. Preferential migration of transferred primordial germ cells to left germinal ridge of recipient embryos in chickens. $J$ Poult $\mathrm{SCi}$ 2009; 46: 40-45. [CrossRef]

20. Ukeshima A, Fujimoto T. A fine morphological study of germ cells in asymmetrically developing right and left ovaries of the chick. Anat Rec 1991; 230: 378-386. [Medline] [CrossRef]

21. Calhim S, Birkhead TR. Intraspecific variation in testis asymmetry in birds: evidence for naturally occurring compensation. Proc Biol Sci 2009; 276: 2279-2284. [Medline] [CrossRef]

22. Minematsu T, Tajima A, Kanai Y. The migratory ability of gonadl germ cells in the domestic chicken. J Poult Sci 2004; 41: 178-185. [CrossRef]

23. Ishiguro S, Minematsu T, Naito M, Kanai Y, Tajima A. Migratory ability of chick primordial germ cells transferred into quail embryos. J Reprod Dev 2009; 55: 183-186. [Medline] [CrossRef]

24. Doitsidou M, Reichman-Fried M, Stebler J, Köprunner M, Dörries J, Meyer D, Esguerra CV, Leung T, Raz E. Guidance of primordial germ cell migration by the chemokine SDF-1. Cell 2002; 111: 647-659. [Medline] [CrossRef]

25. Knaut H, Werz C, Geisler R, Nüsslein-Volhard C, Tübingen 2000 Screen Consortium. A zebrafish homologue of the chemokine receptor Cxcr4 is a germ-cell guidance receptor. Nature 2003; 421: 279-282. [Medline] [CrossRef]

26. Ara T, Nakamura Y, Egawa T, Sugiyama T, Abe K, Kishimoto T, Matsui Y, Nagasawa T. Impaired colonization of the gonads by primordial germ cells in mice lacking a chemokine, stromal cell-derived factor-1 (SDF-1). Proc Natl Acad Sci USA 2003; 100 5319-5323. [Medline] [CrossRef]

27. Molyneaux KA, Zinszner H, Kunwar PS, Schaible K, Stebler J, Sunshine MJ, O'Brien W, Raz E, Littman D, Wylie C, Lehmann R. The chemokine SDF1/CXCL12 and its receptor CXCR4 regulate mouse germ cell migration and survival. Development 2003; 130: 4279-4286. [Medline] [CrossRef]

28. Stebler J, Spieler D, Slanchev K, Molyneaux KA, Richter U, Cojocaru V, Tarabykin V, Wylie C, Kessel M, Raz E. Primordial germ cell migration in the chick and mouse embryo: the role of the chemokine SDF-1/CXCL12. Dev Biol 2004; 272: 351-361. [Medline] [CrossRef]

29. Elbrecht A, Smith RG. Aromatase enzyme activity and sex determination in chickens Science 1992; 255: 467-470. [Medline] [CrossRef]

30. Yoshida K, Shimada K, Saito N. Expression of P450( $\left(_{17 \alpha}\right)$ hydroxylase and P450 aromatase genes in the chicken gonad before and after sexual differentiation. Gen Comp Endocrinol 1996; 102: 233-240. [Medline] [CrossRef]

31. Park TS, Hong YH, Kwon SC, Lim JM, Han JY. Birth of germline chimeras by transfer of chicken embryonic germ (EG) cells into recipient embryos. Mol Reprod Dev 2003; 65: 389-395. [Medline] [CrossRef] 